\title{
Deformed wing virus prevalence and load in honeybees in South Africa
}

\author{
Flaviane S. de Souza ${ }^{1,2} \cdot$ Michael H. Allsopp ${ }^{3}$. Stephen J. Martin ${ }^{1}$ (i)
}

Received: 16 July 2020 / Accepted: 16 September 2020 / Published online: 2 November 2020

(c) The Author(s) 2020

\begin{abstract}
Deformed wing virus (DWV) is an emerging honeybee pathogen that has appeared across the globe in the past 40 years. When transmitted by the parasitic varroa mite, it has been associated with the collapse of millions of colonies throughout the Northern Hemisphere. However, despite the presence of the mite in the Southern Hemisphere, infested colonies survive. This study investigated the prevalence of DWV genotypes A, B and C along with their viral loads in South Africa and compared the findings with recent data from Brazil, the UK and the USA. We found that DWV-B was the most prevalent genotype throughout South Africa, although the total DWV viral load was significantly lower (2.8E+07) than found in the Northern Hemisphere (2.8E+07 vs. $2.7 \mathrm{E}+10, p>0.00001)$ and not significantly different to that found in Brazil $(5 \mathrm{E}+06, p=0.13)$. The differences in viral load can be explained by the mite resistance in Brazil and South Africa, since mite-infested cells containing high viral loads are removed by the bees, thus lowering the colony's viral burden. This behaviour is much less developed in the vast majority of honeybees in the Northern Hemisphere.
\end{abstract}

Deformed wing virus (DWV) is a newly emerging pathogen that within 40 years from its discovery has become the most widespread insect virus. DWV has been detected in over $50 \%$ of all honeybee colonies in 32 countries at high viral loads and in 65 arthropod species spanning eight orders [1]. Prior to the global spread of a highly pathogenic parasitic mite, Varroa destructor, there was a least one known honey bee colony collapse linked to high DWV loads $\left(>10^{7}\right.$ viral particles/bee) (unpublished data, SJM). Recently, more-sensitive testing has shown that the DWV prevalence in varroafree honeybee populations is highly variable, being absent in Australia [2], low in Hawaii [3], and high in Newfoundland [4], but viral loads are typically very low. The recent success of DWV is due to its close association with an ectoparasitic mite (Varroa destructor) that lives on honeybees and

Handling Editor: T. K. Frey.

Stephen J. Martin

s.j.martin@salford.ac.uk

1 School of Environment and Life Sciences, The University of Salford, Manchester M5 4WT, UK

2 Universidade Federal do Recôncavo da Bahia, Rua Rui Barbosa 710, Cruz das Almas, Bahia 44380-000, Brazil

3 ARC-Plant Protection Research Institute, P/Bag X5017, Stellenbosch 7599, South Africa during the past 70 years has spread globally [5]. Molecular evolutionary clocks [6] have demonstrated the possible appearance of widespread DWV-related pathologies with the arrival of Varroa mites. The mite has introduced a new viral transmission route when feeding on the honeybee, causing elevated DWV levels and selecting for highly virulent DWV variants [4] or the appearance of pathogenic strains that outcompete other DWV variants [7]. It is these virulent variants that contribute to the death of the colony. DWV consists of three master-variants (DWV-A, -B, and -C) and various recombinants, each with a different prevalence [8]. In North America and the UK, DWV-A was initially the dominant genotype, but over the past 20 years, DWV-B prevalence has increased in the USA [9] or has almost replaced the DWV-A variant in the UK [10]. DWV-C remains a rare variant. However, little is known about the distribution of DWV variants outside these two countries, especially those in the Southern Hemisphere, where natural resistance to the varroa mite is frequency found [11].

Therefore, the aim of this study was to determine the viral load and prevalence of the three DWV master-variants (A, B and C) in South Africa. South Africa has two honeybee subspecies, the Cape honeybee (Apis mellifera capensis), which is found in the southern fynbos ecosystem, and the Savanna honeybee (A. m. scutellata), which is found throughout the rest of the country (Fig. 1a). Both subspecies are resistant to 

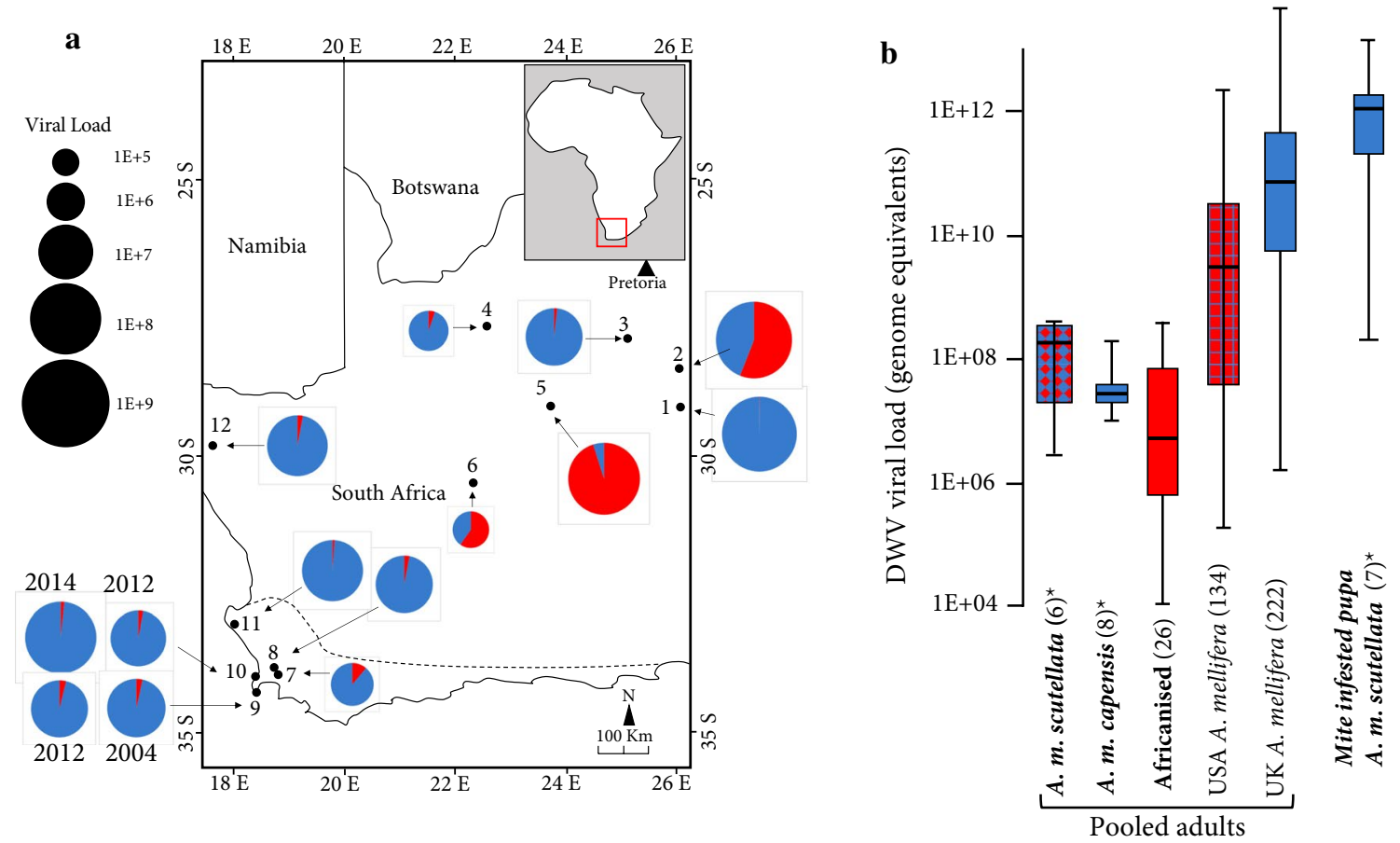

Fig. 1 a DWV load and prevalence (DWV-A, red; DWV-B, blue) throughout South Africa. The area south of the dotted line is occupied by $A$. $m$. capensis, the area north of the line is occupied by $A$. $m$. scutellata, and there is a hybrid buffer contact zone that expends $300 \mathrm{~km}$ north of the dotted line. Sampling locations are as follows: 1, Bloemfontein; 2, Theunissen; 3, Christiana; 4,Tswalu Kalahari; 5, Douglas; 6, Three Sisters; 7, Le Verger; 8, Drie Koppen; 9, Cape

many of the pathogens and parasites that plague honeybee populations in the Northern Hemisphere and thus require limited pest management [12]. Most importantly, after the arrival of the varroa mite in 1997 to the Cape Region of South Africa [13], mite resistance appeared after 3-5 years and 6-7 years in Cape and Savanna honeybees, respectively [14]. Globally, the natural evolution of mite resistance in A. mellifera honeybees is an uncommon trait, since biannual or annual acaricides treatments are required to ensure a colony's survival. Thus, we used honeybee samples of both subspecies collected across the south of the country to compare DWV variant distribution and viral load.

Between 2007 and 2018, 20 colonies were sampled from 12 locations across South Africa (Table 1; Fig. 1a). Each sample consisted of several hundred adult bees collected from brood frames and stored at $-20{ }^{\circ} \mathrm{C}$. In addition, a single sample of adult bees was collected in 2004 from Cape Point. In 2018, seven A. m. scutellata mite-infested pupae were sampled from two locations (Douglas and Three Sisters), since this gives us the best chance of confirming the presence or absence of DWV. Pools of 10 adult bees or one infested pupa from each colony were analysed using an assay developed recently by Kevill et al. [15]. Briefly, RNA
Point; 10, Robben Island; 11,- Langebaan; 12, Nababeep. b Comparison of the DWV viral load and genotype in this study (*) with these found in several other countries. Mite-resistant populations are in bold, and the number of colonies sampled is in parentheses. Where neither DWV-A (red) nor DWV-B (blue) dominates, the most prevalent variant is indicated by the base colour of the hatched pattern

was extracted from a 30-mg sub-sample of the pool bees or single pupa, which were ground to a power using a pestle and mortar in liquid nitrogen. After the RNA was quantified using a NanoDrop spectrophotometer, each sample was diluted to $50 \mathrm{ng} / \mu \mathrm{l}$. RT-PCR was performed using a SensiFAST SYBR No-Rox One-Step Kit with primers specific designed to recognize the RdRp region of the DWV genomic RNA to separate out DWV-A, DWV-B, and DWV-C variants of the RdRp gene. A small number of DWV-A and DWV-B samples were sequenced to confirm their identity. Viral load was expressed as genome equivalents per bee, using the following equations [15]:

(1) copy number RNA = (concentration RNA $(\mathrm{ng} / \mathrm{L}) \times$ $\left.6.022 \times 10^{23}\right) /($ fragment length base pairs $\times 109 \times$ $325)$

(2) genome equivalents $=$ (average copy number RNA) $\times$ $($ RNA dilution factor $) \times($ elution volume of RNA $) \times$ (proportion of bee material)

All statistical comparisons of viral load were conducted using the Mann-Whitney U test due to the non-normal 
Table 1 Collection and viral data for each colony sample of A. m. scutellata and A. m. capensis adults or A. m. scutellata mite-infested pupae

\begin{tabular}{|c|c|c|c|c|c|c|}
\hline Bee race & Location & $\begin{array}{l}\text { Location code } \\
\text { (Fig. 1a) }\end{array}$ & Year collected & $\begin{array}{l}\text { Genome equiva- } \\
\text { lents DWV-A }\end{array}$ & $\begin{array}{l}\text { Genome equiva- } \\
\text { lents DWV-B }\end{array}$ & $\begin{array}{l}\text { Genome } \\
\text { equivalents } \\
\text { DWV-C }\end{array}$ \\
\hline & Pooled adult workers & & & & & \\
\hline A. m. scutellata & Bloemfontein & 1 & 2017 & $5.55 \mathrm{E}+05$ & $3.05 \mathrm{E}+08$ & $0.00 \mathrm{E}+00$ \\
\hline A. m. scutellata & Theunissen & 2 & 2017 & $2.41 \mathrm{E}+08$ & $1.89 \mathrm{E}+08$ & $0.00 \mathrm{E}+00$ \\
\hline A. m. scutellata & Christiana & 3 & 2017 & $9.23 \mathrm{E}+05$ & $5.35 \mathrm{E}+07$ & $0.00 \mathrm{E}+00$ \\
\hline A. m. scutellata & Tswalu Kalahari & 4 & 2007 & $4.62 \mathrm{E}+05$ & $8.46 \mathrm{E}+06$ & $0.00 \mathrm{E}+00$ \\
\hline A. m. scutellata & Douglas & 5 & 2008 & $3.33 \mathrm{E}+08$ & $1.73 \mathrm{E}+07$ & $0.00 \mathrm{E}+00$ \\
\hline A. m. scutellata & Three Sisters & 6 & 2017 & $1.57 \mathrm{E}+06$ & $1.06 \mathrm{E}+06$ & $0.00 \mathrm{E}+00$ \\
\hline A.m. capensis & Le Verger & 7 & 2008 & $7.28 \mathrm{E}+05$ & $2.40 \mathrm{E}+07$ & $0.00 \mathrm{E}+00$ \\
\hline A. m. capensis & Drie Koppen & 8 & 2017 & $1.11 \mathrm{E}+06$ & $8.83 \mathrm{E}+06$ & $0.00 \mathrm{E}+00$ \\
\hline A. m. capensis & Cape Point & 9 & 2004 & $1.05 \mathrm{E}+06$ & $2.95 \mathrm{E}+07$ & $0.00 \mathrm{E}+00$ \\
\hline A. m. capensis & Cape Point 2 & 9 & 2012 & $9.82 \mathrm{E}+05$ & $2.53 \mathrm{E}+07$ & $0.00 \mathrm{E}+00$ \\
\hline A. m. capensis & Robben Island & 10 & 2012 & $1.65 \mathrm{E}+06$ & $5.58 \mathrm{E}+07$ & $0.00 \mathrm{E}+00$ \\
\hline A. m. capensis & Robben Island 2 & 10 & 2014 & $3.26 \mathrm{E}+06$ & $2.03 \mathrm{E}+08$ & $0.00 \mathrm{E}+00$ \\
\hline A. m. capensis & Langebaan & 11 & 2017 & $1.99 \mathrm{E}+05$ & $1.84 \mathrm{E}+07$ & $0.00 \mathrm{E}+00$ \\
\hline \multirow[t]{2}{*}{ A. m. cape/scut hybrid } & Nababeep & 12 & 2008 & $6.22 \mathrm{E}+05$ & $2.08 \mathrm{E}+07$ & $0.00 \mathrm{E}+00$ \\
\hline & Mite-Infested pupae & & & & & \\
\hline A. m. scutellata & Douglas/Stellenbosch (1) * & 5 & 2018 & $2.66 \mathrm{E}+06$ & $2.04 \mathrm{E}+08$ & $4.19 \mathrm{E}+07$ \\
\hline A. m. scutellata & Douglas/Stellenbosch (2) * & 5 & 2018 & $7.94 \mathrm{E}+06$ & $2.43 \mathrm{E}+12$ & $2.33 \mathrm{E}+09$ \\
\hline A. m. scutellata & Douglas/Stellenbosch (3) * & 5 & 2018 & $6.10 \mathrm{E}+06$ & $4.02 \mathrm{E}+12$ & $2.04 \mathrm{E}+08$ \\
\hline A. m. scutellata & Douglas/Stellenbosch (4) * & 5 & 2018 & $1.57 \mathrm{E}+06$ & $1.30 \mathrm{E}+09$ & $0.00 \mathrm{E}+00$ \\
\hline A. m. scutellata & Three Sisters (1) & 6 & 2018 & $3.48 \mathrm{E}+06$ & $5.64 \mathrm{E}+11$ & $2.14 \mathrm{E}+08$ \\
\hline A. m. scutellata & Three Sisters (2) & 6 & 2018 & $1.03 \mathrm{E}+06$ & $1.04 \mathrm{E}+12$ & $7.02 \mathrm{E}+08$ \\
\hline A. m. scutellata & Three Sisters (3) & 6 & 2018 & $2.42 \mathrm{E}+06$ & $2.32 \mathrm{E}+12$ & $7.63 \mathrm{E}+08$ \\
\hline
\end{tabular}

*Colonies moved from Douglas in 2008 to the Stellenbosch area

data distribution, and median load values are presented throughout.

We found that, throughout South Africa, the DWV-B variant is the prevalent genotype in adult bees especially in A. m. capensis, with DWV-A being more prevalent in just three locations, all occupied by A. m. scutellata (Table 1; Fig. 1a). Furthermore, the viral loads in adults of South African honeybees were significantly lower $(\mathrm{U}=702, p<$ 0.00001) lower than the viral loads of DWV in the Northern Hemisphere, i.e., UK and USA, but not significantly different $(\mathrm{U}=112, p=0.13)$ to that found in Brazil [16], where the honeybee population is also resistant to $V$. destructor. The same analytical pipeline [15] was followed in all these studies. The viral levels in the seven A. m. scutellata miteinfested pupae sampled in this study (Table 1 ) were significantly higher $(1 \mathrm{E}+12$ vs. $2 \mathrm{E}+08, \mathrm{U}=0, p=0.0034)$ than present in adults, as expected [17]; however, they were dominated by the DWV-B genotype, whereas previous collected adults contained mainly DWV-A. Again, this is not uncommon, since viral genotypes in a location are variable over time [10]. Furthermore, DWV-A/B recombinants may exist but would not be detected using this method. The infested pupae were the only samples in which DWV-C was detected (Table 1), and its rarity is typical of this variant in adult honeybees studied in the USA, the UK [10] and Brazil [16].

The only previous viral survey of $A$. $m$. scutellata, mainly in the Pretoria area, failed to detect DWV-A in any of the samples, but DWV-B was detected in four apiaries [18], supporting the prevalence of DWV-B in South Africa. A colony with high loads of DWV (detected using ELISA) was reported in South Africa prior to the arrival of varroa mites in 1997 [19], indicating that DWV was circulating in South Africa prior to the arrival of the varroa mites.

A comparable study was conducted across Brazil [16], where Africanised bees are common. These are a man-made hybrid between A. m. scutellata from South Africa and honeybees from Europe. Africanised bees are also resistant to varroa mites, and despite the mite's presence since the 1970s and 1980s, Brazil remains unique in that DWV-A remains the dominant genotype throughout the country, with DWV-B dominating in only one of 26 colonies studied [16]. This is unexpected, since under both controlled $[20,21]$ and natural field conditions $[9,10]$, DWV-B outcompetes and replaces DWV-A. This competition explains why there is 
no significant difference $\left(\chi^{2}=3.3, p=0.07\right)$ between the number of DWV-A- or DWV-B-dominant colonies between the UK [10] and South Africa, which have both been infested with varroa mites for over 30 years. Similarly, in the USA in 2010, DWV-B dominated just 3\% of colonies, but this figure rose to $66 \%$ in 2016 [9], indicating the speed of change.

While the honeybees in Brazil and South Africa are both resistant to varroa mites, they have different DWV genotypes. However, in both countries, the viral load is significantly lower than in the UK or the USA (Fig. 1b). This may be explained by the finding that, in both Brazil and South Africa, the adult workers detect and remove a greater amount of infested brood [22] than is the case in the Northern Hemisphere, thereby reducing the viral burden on the colony. Although the highest viral loads were detected in mite-infested pupae, over $50 \%$ are removed by the bees prior to maturity [22], and the remaining infested pupae have reduced longevity as adults. Both of these factors greatly reduce the viral load in adult bees, as was seen in South Africa and Brazil, but not in the UK or the USA (Fig. 1b), where the rate of removal of mite-infested pupae is low.

Some caution is required in interpreting these results, since the data are derived from a small number of colonies sampled over an 11-year period. Now, a more systematic approach [see 9, 10] across South Africa and beyond is needed to understand the wider impact of DWV on African honeybees. However, based on the current data, it may be the lower viral loads found in South Africa and Brazil rather than the variant (DWV-A vs DWV-B) that reduces the burden of DWV on the honeybees.

Funding This study was funded by Conselho Nacional de Desenvolvimento Científico e Tecnológico (CNPq) (208427/2017-1) to FSdS and in part funded by Aps_M to SJM.

\section{Compliance with ethical standards}

Conflict of interest All authors declare they have no conflict of interest.

Ethical approval This article does not contain any studies with animals requiring ethical approval.

Open Access This article is licensed under a Creative Commons Attribution 4.0 International License, which permits use, sharing, adaptation, distribution and reproduction in any medium or format, as long as you give appropriate credit to the original author(s) and the source, provide a link to the Creative Commons licence, and indicate if changes were made. The images or other third party material in this article are included in the article's Creative Commons licence, unless indicated otherwise in a credit line to the material. If material is not included in the article's Creative Commons licence and your intended use is not permitted by statutory regulation or exceeds the permitted use, you will need to obtain permission directly from the copyright holder. To view a copy of this licence, visit http://creativecommons.org/licenses/by/4.0/.

\section{References}

1. Martin SJ, Brettell LE (2019) Deformed wing virus in honeybees and other insects. Annu Rev Virol 6:121-1221

2. Roberts JM, Anderson DL, Durr PA (2017) Absence of deformed wing virus and Varroa destructor in Australia provides unique perspectives on honeybee viral landscapes and colony losses. Sci Rep 7:6925

3. Martin SJ, Highfield AC, Brettell L et al (2012) Global honeybee viral landscape altered by a parasitic mite. Science 336:1304-1306

4. Shutler D, Head K, Burgher-MacLellan KL et al (2014) Honey bee Apis mellifera parasites in the absence of Nosema cerana fungi and Varroa destructor mites. PLOS ONE 9:e98599

5. Nazzi F, Conte YL (2016) Ecology of Varroa destructor, the major ectoparasite of theWestern honey bee Apis mellifera. Annu Rev Entomol 61:417-432

6. Wilfert L, Long G, Leggett $\mathrm{HC}$ et al (2016) Deformed wing virus is a recent global epidemic in honeybees driven by Varroa mites. Science 351:594-597

7. Ryabov EV, Wood GR, Fannon JM et al (2014) A virulent strain of deformed wing virus (DWV) of honeybees (Apis mellifera) prevails after Varroa destructor-mediated, or in vitro, transmission. PLoS Pathog 10:e1004230

8. Mordecai GJ, Wilfert L, Martin SJ et al (2016) Diversity in a honey bee pathogen: first report of a third master variant of the Deformed Wing Virus quasispecies. ISME J 10:1264-1273

9. Ryabov EV, Childers AK, Chen Y et al (2017) Recent spread of Varroa destructor virus-1, a honey bee pathogen in the United States. Sci Rep 7:17447

10. Kevill JL, de Souza FS, Sharples C et al (2019) DWV-A lethal to honey bees (Apis mellifera): A colony level survey of DWV variants (A, B \& C) in England, Wales and 32 states across the US. Viruses 11:426

11. Mondet F, Beaurepaire A, McAfee A et al (2020) Honey bee survival mechanisms against the parasite Varroa destructor: a systematic review of phenotypic and genomic research efforts. Inter J Parasitol 50:433-447

12. Pirk CWW, Strauss U, Yusuf AA et al (2015) Honey bee health in Africa-a review. Apidologie 47:276-300

13. Allsopp M, Govan V, Davison S (1997) Bee health report: Varroa in South Africa. Bee World 78:171-174

14. Allsopp MH (2006) Analysis of Varroa destructor infestation of southern African honeybee populations. MSc dissertation. University of Pretoria, Pretoria, South Africa

15. Kevill JL, Highfield A, Mordecai GJ et al (2017) ABC Assay: method development and application to quantify the role of three DWV master variants in overwinter colony losses of European honey bees. Viruses 9:314

16. de Souza FS, Kevill JL, Correia-Oliveira ME et al (2019) Occurrence of deformed wing virus variants in the stingless bee Melipona subnitida and honey bee Apis mellifera populations in Brazil. J Gen Virol 100:289-294

17. Mordecai GJ, Brettell L, Martin SJ et al (2016) Superinfection exclusion and the long-term survival honey bees in Varroainfested colonies. ISEM J 10:1182-1191

18. Strauss U, Human H, Gauthier L et al (2013) Seasonal prevalence of pathogens and parasites in the savannah honeybee (Apis mellifera scutellata). J Invertebr Pathol 114:45-52

19. Allen M, Ball B (1996) The incidence and world distribution of honeybee viruses. Bee World 77:141-162 
20. McMahon DP, Natsopoulou ME, Doublet V et al (2016) Elevated virulence of an emerging viral genotype as a driver of honeybee loss. Proc R Soc B 283(2016):0811

21. Norton AM, Remnant EJ, Buchmann GB (2020) Accumulation and competition amongst Deformed Wing Virus genotypes in naïve Australian honeybees provides insight into the increasing global prevalence of genotype B. Front Microbiol 11:620

22. Martin SJ, Hawkins GP, Brettell LE et al (2019) Varroa destructor reproduction and cell re-capping in mite-resistant Apis mellifera populations. Apidologie 51:369-381
Publisher's Note Springer Nature remains neutral with regard to jurisdictional claims in published maps and institutional affiliations. 